\title{
Phytophthora palmivora Causing Disease on Theobroma cacao in Hawaii
}

\author{
Alina Sandra Puig ${ }^{1, * \mathbb{D}}$, Wilber Quintanilla ${ }^{1}$, Tracie Matsumoto ${ }^{2}$, Lisa Keith ${ }^{2} \mathbb{D}$, Osman Ariel Gutierrez ${ }^{1}$ \\ and Jean-Philippe Marelli ${ }^{3}$ \\ 1 Subtropical Horticultural Research Station, USDA-ARS, Miami, FL 33158, USA; \\ wil.quintanilla@usda.gov (W.Q.); osman.gutierrez@usda.gov (O.A.G.) \\ 2 Daniel K. Inouye U.S. Pacific Basin Agriculture Research Center, USDA-ARS, Hilo, HI 96720, USA; \\ tracie.matsumoto@usda.gov (T.M.); lisa.keith@usda.gov (L.K.) \\ 3 Mars Plant Sciences Laboratory, Davis, CA 95616, USA; jean-philippe.marelli@effem.com \\ * Correspondence: alina.puig@usda.gov
}

check for updates

Citation: Puig, A.S.; Quintanilla, W.; Matsumoto, T.; Keith, L.; Gutierrez, O.A.; Marelli, J.-P. Phytophthora palmivora Causing Disease on Theobroma cacao in Hawaii. Agriculture 2021, 11, 396. https://doi.org/ 10.3390/agriculture11050396

Academic Editor: Roy Kennedy

Received: 30 March 2021

Accepted: 22 April 2021

Published: 27 April 2021

Publisher's Note: MDPI stays neutral with regard to jurisdictional claims in published maps and institutional affiliations.

Copyright: (c) 2021 by the authors. Licensee MDPI, Basel, Switzerland. This article is an open access article distributed under the terms and conditions of the Creative Commons Attribution (CC BY) license (https:// creativecommons.org/licenses/by/ $4.0 /)$.

\begin{abstract}
Commercial production of cacao in Hawaii has doubled in the past 10 years, and farmers are receiving premium prices for their beans from the expanding local confectionery industry. Black pod, caused by Phytophthora spp., is the only major cacao disease that has been reported in Hawaii but distribution and molecular identification are lacking. To determine the species of Phytophthora affecting Theobroma cacao, a sampling trip was conducted on Hawaii Island and Oahu. Ten isolates of Phytophthora palmivora were obtained from diseased cacao on Hawaii Island, but none from Oahu, despite the presence of symptomatic pods. No other Phytophthora species were found. Laboratory studies showed that all isolates produced lesions on unwounded cacao pods, but they differed in terms of their temperature-growth responses. Fungicide sensitives for a subset of isolates $(n=4)$ were determined using media amended with a range of fungicide concentrations. The Hawaiian isolates of $P$. palmivora were more sensitive to mefenoxam, chlorothalonil, and fosetyl-Al, than isolates from Ghana $(n=2)$ and Mexico $(n=1)$. This study identifies $P$. palmivora as a causal agent of black pod in Hawaii based on molecular data and provides valuable preliminary information on fungicide resistance and temperature response that can be used to improve disease management.
\end{abstract}

Keywords: black pod rot; cocoa; Phytophthora canker; etiology; zoospores

\section{Introduction}

Commercial production of cacao (Theobroma cacao L.) in Hawaii is increasing, with farms now present on most of the islands [1]. Most farms are young and small-scale (0.4-0.8 hectares), with an economic model that relies on niche markets and value-added processing [2,3]. Among tropical fruit and specialty crops in Hawaii, cacao is the 8th highest value, with USD 88,000 in sales in 2016 [4]. Since 2008, an estimated 19,000 cacao trees have been planted in the state, bringing the commercial production area to 138 hectares, making it the crop to experience the greatest expansion in production in the state.

Cacao production in this area faces unique challenges because the Hawaii Islands are located partly outside of the 20-degree latitude zone $\left(18^{\circ} 54^{\prime} 36^{\prime \prime}\right.$ to $\left.22^{\circ} 13^{\prime} 48^{\prime \prime}\right)$ recommended for commercial production, and experience temperatures below the optimal range for the plant. However, the absence of the most severe cacao diseases (Cacao swollen-shoot virus disease, frosty pod rot, witches broom, Ceratocystis wilt, and vascular streak dieback) gives the Hawaiian cacao industry an advantage over other locations [5].

The importance of disease, specifically black pod rot (BPR), has increased, with diseases being rated the most important issue facing the Hawaii cacao to chocolate industry [3]. Globalization has led to an increase in trade and travel, and pathogenic organisms are being introduced to new locations at a high rate [6]. Accidental importation is a potential 
entryway for cacao diseases and pests in Hawaii, as micro-organisms can be unknowingly brought in on pods, seeds, plants, or budwood.

Phytophthora spp. cause greater yield losses than any other pathogen on cacao, approximately 20-30\% annually [7]. Several Phytophthora spp. cause BPR and canker, of which P. palmivora (Butl.) Butler is the most prevalent. Strategies to control infection include frequent removal and disposal of infected pods, which shrivel yet remain in the tree canopy, providing a source of inoculum for several years [8]. Under conditions of high humidity or precipitation, each mummified pod can produce millions of sporangia which are then disseminated by rain, insects, or harvesting tools [9]. Although cultural controls alone have effectively managed disease in areas of Ghana [10], they are usually combined with fungicide applications. Chlorothalonil, mancozeb, mefenoxam, and fosetyl-Al are among the fungicides active against oomycetes and their effectiveness against Phytophthora has been well-established.

As no studies of Phytophthora spp. on cacao farms in Hawaii have been published, a small-scale survey of farms on Hawaii Island and Oahu was conducted in January 2018 to determine the presence and prevalence of Phytophthora spp. The eight sites represented a range of environmental conditions (temperature, precipitation, elevation). The objectives of this study were to (i) identify the species of Phytophthora associated with diseased cacao plants in Hawaii based on genetic sequences, (ii) determine phenotypic (temperature response, zoospore production, and virulence) variability of local isolates, and (iii) establish baseline sensitivities to four fungicides active against oomycetes.

\section{Materials and Methods}

\subsection{Pathogen Isolation}

Pods and stems showing symptoms of Phytophthora infection (firm, brown/black lesions on pods and reddish lesion discoloration below bark on stems) were sampled and taken to the USDA ARS Daniel K. Inouye U.S. Pacific Basin Agricultural Research Center in Hilo for isolation and preliminary identification (Figure 1).

To increase the likelihood of isolating Phytophthora from infected material, samples were baited into healthy, 3-4-month-old cacao pods [11]. This method improves isolation results by acting as a differential medium for Phytophthora and filtering out saprophytes and secondary organisms present in the original sample. In this study, "bait" pods were cut in half length-wise, with each half containing 3-4 subsections a single sample (1 symptomatic pod or 1 symptomatic stem) (Figure 2).

Symptomatic pods were processed by excising pieces (approximately $3 \times 15 \times 3 \mathrm{~mm}^{3}$ ) from lesion margins comprising both healthy and necrotic tissue, surface-disinfesting by immersing in $70 \%$ ethanol for $20 \mathrm{~s}$, and air drying on autoclaved filter paper. These pieces were then cut into $1 \times 5 \times 3 \mathrm{~mm}^{3}$ strips with a sterile scalpel and inserted into openings of similar size that had been cut into healthy bait pods.

Stem samples were taken from the expanding edge of cankers and contained both healthy and symptomatic tissue. They were surface-sterilized as described above, cut into wedges (approximately $3 \times 15 \times 8 \mathrm{~mm}^{3}$ ), and inserted into openings of similar size made in the bait pod. Baited pods were wrapped in parafilm to secure inserted tissue and prevent desiccation, then placed in a Ziploc bag and incubated at room temperature $\left(25 \pm 3{ }^{\circ} \mathrm{C}\right)$.

After four days, samples containing Phytophthora spp. presented a firm brown discoloration developing around the bait site. Tissue at the margin of these developing lesions was excised, surface disinfested and dissected as described above, plated on $\frac{1}{2}$ strength potato dextrose agar (PDA) (Sigma Chemical Co; $19.5 \mathrm{~g}$ of PDA, $7.5 \mathrm{~g}$ of agar, and $1 \mathrm{~L}$ of distilled water), and incubated at room temperature.

Plates were examined daily for the emergence of slowly growing, non-septate hyphae, which became visible from positive samples after three to five days. Hyphae were subcultured onto to new plates of $\frac{1}{2}$ PDA and visually identified as Phytophthora spp. by the appearance obpyriform sporangia under the microscope within one week (at $50 \times$ magnification). Mycelium was harvested by cutting $\frac{1}{2}$ PDA blocks from colony 
edges and placing in a 1.5-mL sterile microcentrifuge tube, then shipped to the Plant Pathology Laboratory at the USDA-ARS Subtropical Horticulture Research Station (SHRS) at Miami, FL under an Interstate movement permit (\#P526P-16-03047). There, isolates were purified by single hyphal tip transfer and maintained in the dark on $20 \%$ V8 agar (V8A) at room temperature. DNA was extracted from 10-day-old mycelium growing in clarified $20 \%$ V8 broth, using the Qiagen DNeasy Plant Mini Kit (Qiagen, Hilden, Germany). Climate and elevation statistics for each site were compiled from the following databases [12-16]. Databases were selected based on proximity of each weather station to study sites.

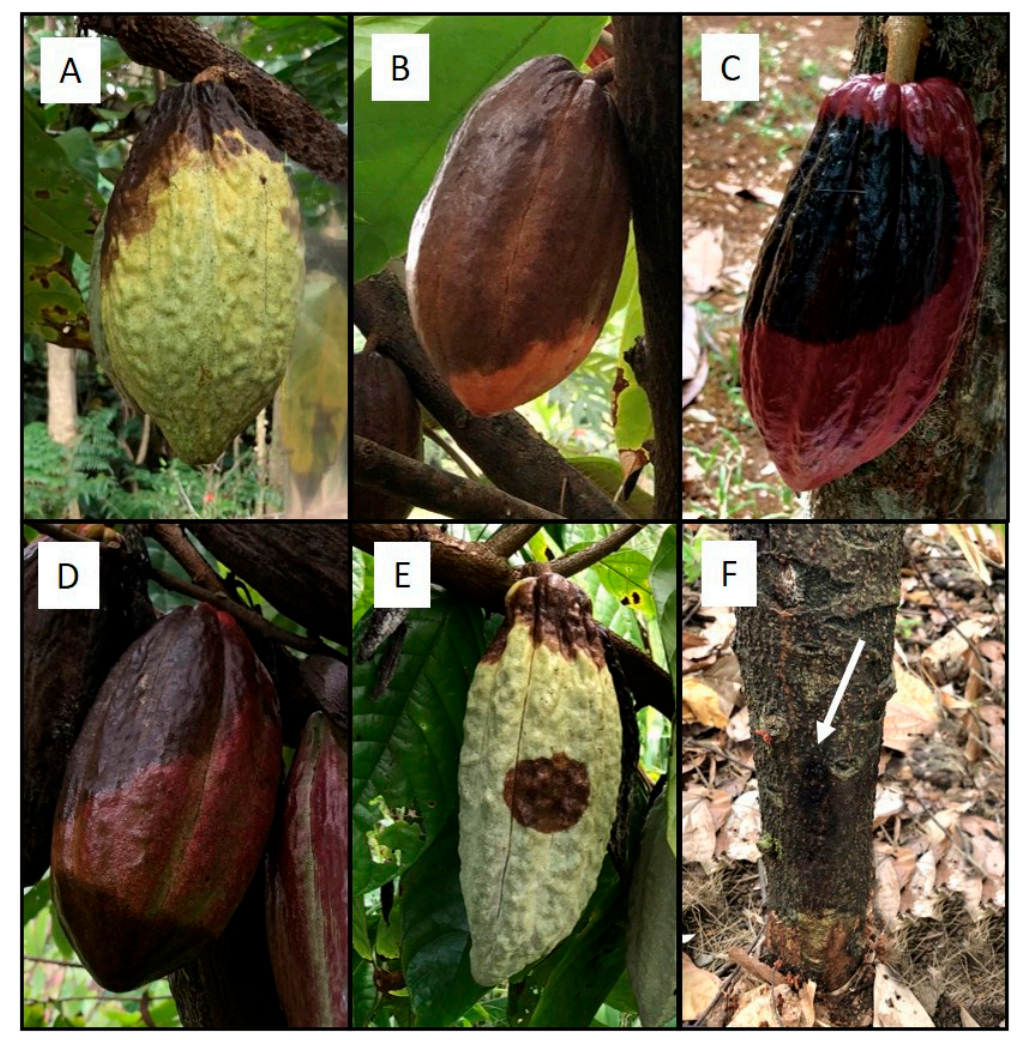

Figure 1. Symptoms of Phytophthora palmivora infection on pods and stem of Theobroma cacao in Hawaii. Necrotic lesions can originate from peduncle (A,B) or infection can occur at points not adjacent to the tree $(\mathbf{C})$. In areas with higher disease incidence, lesions can develop at multiple points on a pod (D,E). P. palmivora also causes stem cankers (F) from which liquid exudes onto outer bark (arrow).

\subsection{Molecular Identification}

To identify the organisms isolated, the internal transcribed spacer (ITS) region (ITS 1, 5.8S rRNA gene and ITS 2) and the cytochrome c oxidase subunit 2 (COX2) were amplified and sequenced. Both have been identified as effective barcoding genes for oomycetes. Primers ITS5 ( $5^{\prime}$ GGA AGT AAA AGT CGT AAC AAG G $\left.3^{\prime}\right)$ and ITS4 ( $5^{\prime}$ TCC TCC GCT TAT TGA TAT GC $3^{\prime}$ ) were used for the ITS region [17], and primers COX2F (5' GGC AAA TGG GTT TTC AAG ATC C $\left.3^{\prime}\right)$ and COX2R ( $5^{\prime}$ GAT TAA TAC CAC AAA TCT CTG AAC $\left.3^{\prime}\right)$ for the COX2 gene [18].

Amplification reactions were performed in $20 \mu \mathrm{L}$ volumes, consisting of $10 \mu \mathrm{L} 2 \times$ GoTaq Green master Mix (Promega, Madison, WI, USA), $0.4 \mu \mathrm{L}$ of each $10 \mu \mathrm{M}$ primer (forward and reverse), $100 \mathrm{ng}$ genomic DNA, and sterile milli-Q water to $20 \mu \mathrm{L}$. Gene regions were amplified using the following thermocycler conditions: $94^{\circ} \mathrm{C}$ for $10 \mathrm{~min}$; then, 30 cycles of $95^{\circ} \mathrm{C}$ for $30 \mathrm{~s}, 57^{\circ} \mathrm{C}$ for $30 \mathrm{~s}$, and $72{ }^{\circ} \mathrm{C}$ for $45 \mathrm{~s}$; followed by a final primer extension step of $72{ }^{\circ} \mathrm{C}$ for $5 \mathrm{~min}$. COX2: Reactions were performed as described above, but with an annealing temperature of $48^{\circ} \mathrm{C}$. 


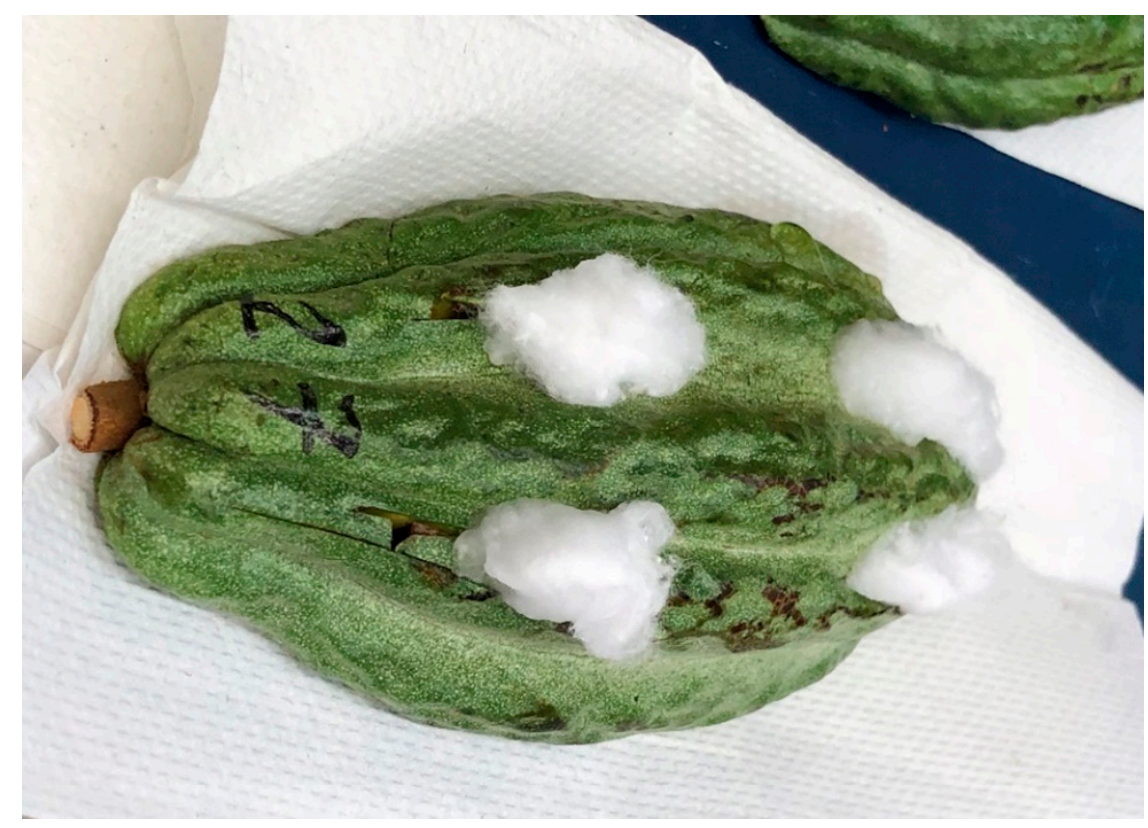

Figure 2. Phytophthora palmivora was isolated from diseased pod and stem samples by surfacesterilizing and inserting tissue into a healthy cacao pod.

The BigDye Terminator v 3.1 Cycle sequencing Kit (Applied Biosystems, Foster City, CA, USA) was used for sequencing reactions, following the manufacturer's protocols, on an ABI PRISM 3730xl genetic analyzer using Pop 7 polymer (Applied Biosystems). Each mixture contained $1.75 \mu \mathrm{L} 5 x$ sequencing buffer (Big Dye), $0.5 \mu \mathrm{L}$ Big Dye Terminator, $0.32 \mu \mathrm{L}$ primer $(10 \mathrm{uM}), 2 \mu \mathrm{L}$ of the PCR product and $5.43 \mu \mathrm{L}$ molecular grade water. The following PCR conditions were followed: initial denaturation at $96{ }^{\circ} \mathrm{C}(1 \mathrm{~min})$, followed by one step at $96^{\circ} \mathrm{C}$ for denaturation of the double stranded DNA (10 s), followed by an annealing step at $50{ }^{\circ} \mathrm{C}(5 \mathrm{~s})$ and primer extension at $60^{\circ} \mathrm{C}(4 \mathrm{~min})$.

Forward and reverse sequences were aligned, edited, and blasted using Geneious 8.1 (Biomatters Ltd., Auckland, New Zealand.) and analyzed in BLASTn to confirm pathogen identity. A subset of these sequences was deposited in GenBank and have the following accession numbers MH936024 (COX2 gene, isolate H9) and MH936024 (ITS region, isolate $\mathrm{H} 12)$.

\subsection{Temperature Growth Response}

The influence of temperature on growth of the ten Hawaii isolates was tested in vitro at a range of temperatures $\left(10^{\circ} \mathrm{C}\right.$ to $35^{\circ} \mathrm{C}$ in $5^{\circ}$ intervals). Agar plugs $(6 \mathrm{~mm})$ from 5-dayold cultures growing at $27 \pm 2{ }^{\circ} \mathrm{C}$ on $20 \%$ V8 agar Petri dishes $\left(85 \times 15 \mathrm{~mm}^{2}\right)$ were placed top side down in the center of new media plates, with four replicates per isolate. The plates were wrapped with parafilm and placed in the dark at the selected temperature for 3 days, after which the diameter $(\mathrm{mm})$ of resulting colonies was measured twice for each plate at right angles to each other. Diameters were averaged (following subtraction of original plug diameter) and divided by 2 , to produce a single mean radial measurement per plate. The experiment was repeated, and data were pooled for summary statistics and graph construction in Excel. A P. palmivora isolate from Ghana, GH49, was used a control. This isolate has been used extensively in temperature growth studies and its response is well documented [19].

\subsection{Zoospore Production}

Zoospore production is an important component of epidemiology and disease spread. Zoospore production of each isolate was quantified using a protocol modified from [19]. Five millimeter diameter plugs were taken from the actively growing margins of 2 to 
5-day-old colonies growing on $20 \% \mathrm{~V} 8$ agar were placed mycelial side down in the center of new $20 \% \mathrm{~V} 8$ agar dishes and placed in the dark at $25^{\circ} \mathrm{C}$ for 5 days, followed by 5 days under continuous light. Zoospore production and release was induced by adding $12 \mathrm{~mL}$ cold sterile water $\left(4^{\circ} \mathrm{C}\right)$ to each plate, then placing them at $4{ }^{\circ} \mathrm{C}$ for $45 \mathrm{~min}$. Plates were then moved to $28^{\circ} \mathrm{C}$ for $28 \mathrm{~min}$, after which the zoospore concentrations (zoospores $/ \mathrm{mL}$ ) were estimated using disposable KOVA Glasstic Slide 10 (KOVA International Inc., Garden Grove, CA, USA). Three samples from each plate were quantified then averaged to get a single zoospore concentration per isolate. To adjust for colony size and obtain a standardized measure, zoospore concentrations were divided by colony area $\left(\mathrm{cm}^{2}\right)$ which was calculated as:

$$
\text { Area }=\pi \times \mathrm{R}^{1} \times \mathrm{R}^{2}
$$

where $R^{1}$ and $R^{2}$ are the largest and smallest radii of the colony, respectively. The assay was carried out as a completely randomized design (CRD), with 3-4 replicates per isolate and experiment conducted twice.

\subsection{Virulence Screening}

To determine relative virulence of isolates, unwounded pod husk inoculation assays were carried out with all confirmed P. palmivora isolates collected. For inoculation, zoospores were produced as described above, and 1000 zoospores (in a $50 \mu \mathrm{L}$ solution) were applied to $3 \times 6 \mathrm{~cm}^{2}$ pieces of unripe cacao pods (clone 'GNV 164', five months old). It was secured by placing a $1 \times 1 \mathrm{~cm}^{2}$ filter paper disc on the inoculum then wrapping in parafilm. To maximize the size of radii that could be measured, inoculum was placed off-center (near one edge).

Pod pieces were placed in sealed plastic bags and incubated in a growth chamber at $25^{\circ} \mathrm{C}$. After four days, lesion radius was measured as the distance from the center of the inoculation site to the lesion margin. Two radii were measured for each pod piece, from which the mean radius was calculated. The assay was carried out as an incomplete unbalanced block design with three separate blocks. Blocks contained 6-7 isolates, with 3-5 replicates each. Each isolate was replicated 4-9 times in the experiment (Supplemental File 1) and sterile water was included as the negative control. To confirm the causal agent as $P$. palmivora, a subset of lesions was sampled as described above for pathogen isolation and identified based on morphology.

\subsection{Fungicide Sensitivity Assay}

An analysis of fungicide sensitivity in vitro was carried out to determine how $P$. palmivora responded to fungicides commonly used in cacao production. Four Hawaii isolates were chosen, ensuring that at least one isolate from each collection site was included (H5, H7, H11, H33). Three reference isolates from diseased cacao in Ghana (GH 49 (GHER1349) and VR100 (GH-VR100)) [19] and Mexico (C18) were included.

Fungicides to be evaluated included chlorothalonil (Daconil, 29\% active ingredient, Syngenta, Greensboro, NC, USA), mancozeb (Mancozeb, 30\% active ingredient $(28.7 \%$ ethylene bisdithiocarbamte, $7.4 \%$ manganese, and $0.9 \%$ zinc ion), Dow AgroSciences LLC, Indianapolis, IN, USA), mefenoxam (Ridomil Gold SL, 48\% active ingredient, Syngenta), and fosetyl-Al (Aliette, 80\% active ingredient, Bayer CropScience, St. Louis, MO, USA). Freshly made stock solutions were prepared and added to autoclaved culture media, to give specific active ingredient concentrations, based on prior published reports. Concentrations used were $0,0.1,1,10$, and $100 \mathrm{ppm}$ for chlorothalonil, mancozeb, and mefenoxam, and 0 , $1,10,100$, and $1000 \mathrm{ppm}$ for fosetyl-Al.

Chlorothalonil, mancozeb, and mefenoxam dilution plates were made by adding corresponding quantities of each compound to V8A media, and fosetyl-Al dilution plates were made using Ribeiro's modified synthetic agar media (RMSM) (1 mg of thiamine HCL solution per milliliter $+15 \mathrm{~g} / \mathrm{L}$ agar). Agar plugs $(5 \mathrm{~mm})$ from 2 to 4-day-old colonies growing on clarified V8 agar were placed top side down in the center of Petri plates containing the selected fungicide by concentration combination. The plates were wrapped 
with parafilm and placed in the dark at $25^{\circ} \mathrm{C}$. The experiments were concluded when the fastest growing isolate reached the edge of the plate. This ended up being 5 days for all fungicide experiments except fosetyl-Al, in which the fastest growing isolate took at least 7 days to fill the plate. At this time, the diameter of resulting colonies was measured twice for each plate at right angles to each other. Each experiment had 4-6 replicates of each isolate by concentration combination, depending on the number of plates available.

Percent inhibition of mycelial growth was calculated as:

$$
\% \text { Inhibition of mycelial growth }=[(\mathrm{Mc}-\mathrm{Mt}) / \mathrm{Mc}] \times 100
$$

where $\mathrm{Mc}=$ mean radius of colony on $0 \mathrm{ppm}$ media and $\mathrm{Mt}=$ mean radius of colony on plates with a given concentration. Experiments were conducted twice.

Additional fosetyl-Al assays. Due to the high variation recorded during the fosetyl$\mathrm{Al}$ assays, the experiment was repeated a total of four times, using a different range of concentrations $(0,0.1,1,10$, and $100 \mathrm{ppm}$ instead of $0,1,10,100$, and $1000 \mathrm{ppm})$.

\subsection{Statistical Analyses}

Differences in temperature growth response among isolates was assessed by conducting an analysis of variance (ANOVA) on radial growth at each temperature. To increase sample size, the two experiments conducted at each temperature were analyzed together as separate blocks in a randomized complete block design (RCBD) using PROC MIXED in SAS Ver. 9.3 (SAS Institute, Cary, NC, USA). Means were separated using Tukey-Kramer Comparison lines for least squares means of the isolates.

To determine whether production differed among isolates, zoospore concentrations were compared using an ANOVA. Experiments were pooled for statistical analysis but due to variability, experiments were analyzed as separate blocks in a RCBD using PROC MIXED. Means were separated using Tukey-Kramer Comparison lines for least squares means of the isolates.

Lesion radii means were compared among isolates using ANOVA using PROC GLM. They were square root transformed for analysis to correct non-normal distribution, and means were separated using Tukey-Kramer Comparison lines for least squares means of the isolate. Non-transformed means were used for figure construction.

For statistical analysis of chlorothalonil, mancozeb, and mefenoxam sensitivity assays, the percent inhibition of each isolate relative to the nonamended control (V8A) was plotted against the $\log _{10}$ of the fungicide concentration. The effective concentration $\left(\mathrm{EC}_{50}\right.$; dose at which $50 \%$ of the growth was inhibited) of each fungicide for each isolate was calculated in Microsoft Excel using Finney's method of probit analysis [20].

The four experiments assessing fosetyl-Al sensitivity were used to calculate a single $\mathrm{EC}_{50}$. For each experiment, the percent inhibition of mycelial growth was averaged to get a single value for each concentration, which was then treated as a replicate (4 replicates of 1,10 , and $100 \mathrm{ppm}$, and 2 replicates of 0.1 and $1000 \mathrm{ppm}$ ). Mean \% inhibition at each concentration was calculated from these replicates and used to estimate $\mathrm{EC}_{50}$ as described previously.

\section{Results}

\subsection{Pathogen Isolation}

Pods with firm, dark brown/black lesions resembling those caused by P. palmivora were observed on five of the eight farms visited, and discolored stem tissue resembling Phytophthora spp. cankers were observed on two of the eight sites visited; however, the pathogen was only isolated from two sites (re. pods) and one site (re. stem), respectively. Isolations from 9 of the 27 total pod samples and one of the eight total stem samples taken were successful (defined by recovery of Phytophthora spp). In terms of pathogen distribution, this translates to two sites with confirmed Phytophthora spp. affecting pods (BPR) and one site with Phytophthora spp. affecting stems (canker disease) (Table 1). Positive samples came exclusively from sites 1,2, and 3, all located near the city of Hilo. 
Table 1. Sites where diseased cacao material was sampled and processed for Phytophthora spp. recovery. P. palmivora was obtained from three sites on Hawaii Island but was not detected on Oahu.

\begin{tabular}{ccccccc}
\hline Site & Island & $\begin{array}{c}\text { Average } \\
\text { Temperature }\end{array}$ & $\begin{array}{c}\text { Annual } \\
\text { Precipitation }\end{array}$ & Elevation & Sample \# and Type & P. Palmivora Isolates \\
\hline 1 & Hawaii & $21.8-24.6^{\circ} \mathrm{C}$ & $3239 \mathrm{~mm}$ & $1 \mathrm{~m}$ & 7 pods & $\mathrm{H} 3, \mathrm{H} 5, \mathrm{H} 6, \mathrm{H} 7, \mathrm{H} 8, \mathrm{H} 9$ \\
2 & Hawaii & $21.3-24.4^{\circ} \mathrm{C}$ & $3365 \mathrm{~mm}$ & $46 \mathrm{~m}$ & 3 pods & $\mathrm{H} 11, \mathrm{H} 12, \mathrm{H} 17$ \\
3 & Hawaii & $21.7-24.6^{\circ} \mathrm{C}$ & $3459 \mathrm{~mm}$ & $29 \mathrm{~m}$ & 7 stems & H33 \\
4 & Hawaii & $16-27^{\circ} \mathrm{C}$ & $467 \mathrm{~mm}$ & $493 \mathrm{~m}$ & 5 pods & None \\
5 & Hawaii & $14.3-24.9^{\circ} \mathrm{C}$ & $577 \mathrm{~mm}$ & $377 \mathrm{~m}$ & 1 stem & None \\
6 & Oahu & $22.1-25.7^{\circ} \mathrm{C}$ & $599 \mathrm{~mm}$ & $19 \mathrm{~m}$ & 6 pods & None \\
7 & Oahu & $17.7-28.2^{\circ} \mathrm{C}$ & $755 \mathrm{~mm}$ & $3 \mathrm{~m}$ & 6 pods & None \\
8 & Oahu & $21.9-27.1^{\circ} \mathrm{C}$ & $814 \mathrm{~mm}$ & $152 \mathrm{~m}$ & 6 pods
\end{tabular}

\# refers to how many samples were collected at each site.

Site 3 was an abandoned cacao plantation, established in the 1980s, it was one of the first commercial plantations on the island [21,22]. Although no developing pods were present at site 3 , trees were observed with stem cankers resembling those caused by $P$. palmivora. Two of the three sites visited on Oahu (sites 6 and 8) had pods with characteristic BPR symptoms, however, no P. palmivora was recovered. No cacao plants with symptoms resembling Phytophthora spp. infection were observed at site 7 in Oahu.

\subsection{Molecular Identification}

The results of the BLASTn of the ITS sequences of the unknown isolates recovered from Hawaii identified them all as P. palmivora, with $100 \%$ sequence identity to cacaooriginating isolates from around the globe (Malaysia KY475632.1, Ghana KY475631.1, Colombia KY475619.1, Costa Rica KR818130.1, Ivory Coast JX315267.1, and Puerto Rico DQ987915.1), as well as P. palmivora from other hosts such as Citrus reticulata in India (KY476632.1), and Rhododendron sp. in Taiwan (KY476632.1).

Of the four COX2 sequences of P. palmivora isolated from cacao available in GenBank, the Hawaii isolates were identical to isolates from Ghana (JF771544.1) and Nigeria (AY129217.1) and 99\% identical to the remaining two accessions (American Samoa JF771545.1 and Brazil AY129218.1). A representative sequence of each, the ITS region (isolate H12, MH936023) and COX2 (isolate H9, MH936024), were deposited in GenBank. No differences among isolates were found among sequences for either region generated in this study.

\subsection{Temperature Growth Response}

Growth among isolates varied at all temperatures tested, except $10^{\circ} \mathrm{C}$, at which no growth was observed. Mean radii differed significantly among isolates at all temperatures tested except $30{ }^{\circ} \mathrm{C}$ and $10{ }^{\circ} \mathrm{C}$ (Figure 3). At $35^{\circ} \mathrm{C}, \mathrm{H} 8$ and $\mathrm{H} 9$ had significantly greater radii than all other isolates apart from $\mathrm{H} 3$. Despite this, radial range was only $2.9 \mathrm{~mm}$ between the highest and lowest. P. palmivora from Hawaii showed greatest growth at $30^{\circ} \mathrm{C}$. GH49, the control from Ghana, had a lower temperature optimum than the isolates from Hawaii, with its maximum mean radius recorded at $25^{\circ} \mathrm{C}(38.4 \pm 0.92 \mathrm{~mm})$, compared with a radial range of $23.3 \mathrm{~mm}(\mathrm{H} 7)$ to $32.3 \mathrm{~mm}$ (H33) for the other isolates. Maximum growth was recorded at $30^{\circ} \mathrm{C}$ for all Hawaiian isolates, with radii ranging from $33.8 \mathrm{~mm}$ $( \pm 1.06 \mathrm{~mm})$ for $\mathrm{H} 9$ to $38.9 \mathrm{~mm}( \pm 0.66 \mathrm{~mm})$ for $\mathrm{H} 8$. In addition, mean radius of GH49 was significantly greater than other isolates at $25^{\circ} \mathrm{C}, 20^{\circ} \mathrm{C}$, and $15^{\circ} \mathrm{C}$, but lower than others at $30^{\circ} \mathrm{C}$ and $35^{\circ} \mathrm{C}$.

\subsection{Zoospore Production}

Zoospore production and release in 10-day-old cultures following thermal shock differed among the isolates of P. palmivora tested $(p<0.0001)$ (Figure 4$)$. No differences were detected among the Hawaiian isolates, which ranged from $6002 \pm 1054$ (H33) to 
$16,171 \pm 2787(\mathrm{H} 3)$ zoospores $/ \mathrm{mL}$ for each $\mathrm{cm}^{2}$ of colony area (total zoospores per $\mathrm{mL}$ divided by colony area). The isolates from Ghana (VR100 and GH49) differed from all Hawaii isolates (except H33), producing significantly fewer zoospores (1339.5 \pm 775 and $192.9 \pm 65$, respectively). The isolate from Mexico (C18) produced $3788 \pm 1144$, only differed significantly from $\mathrm{H} 3$ which produced the greatest number of zoospores $(16,171 \pm 2787)$ per ML/per $\mathrm{cm}^{2}$.

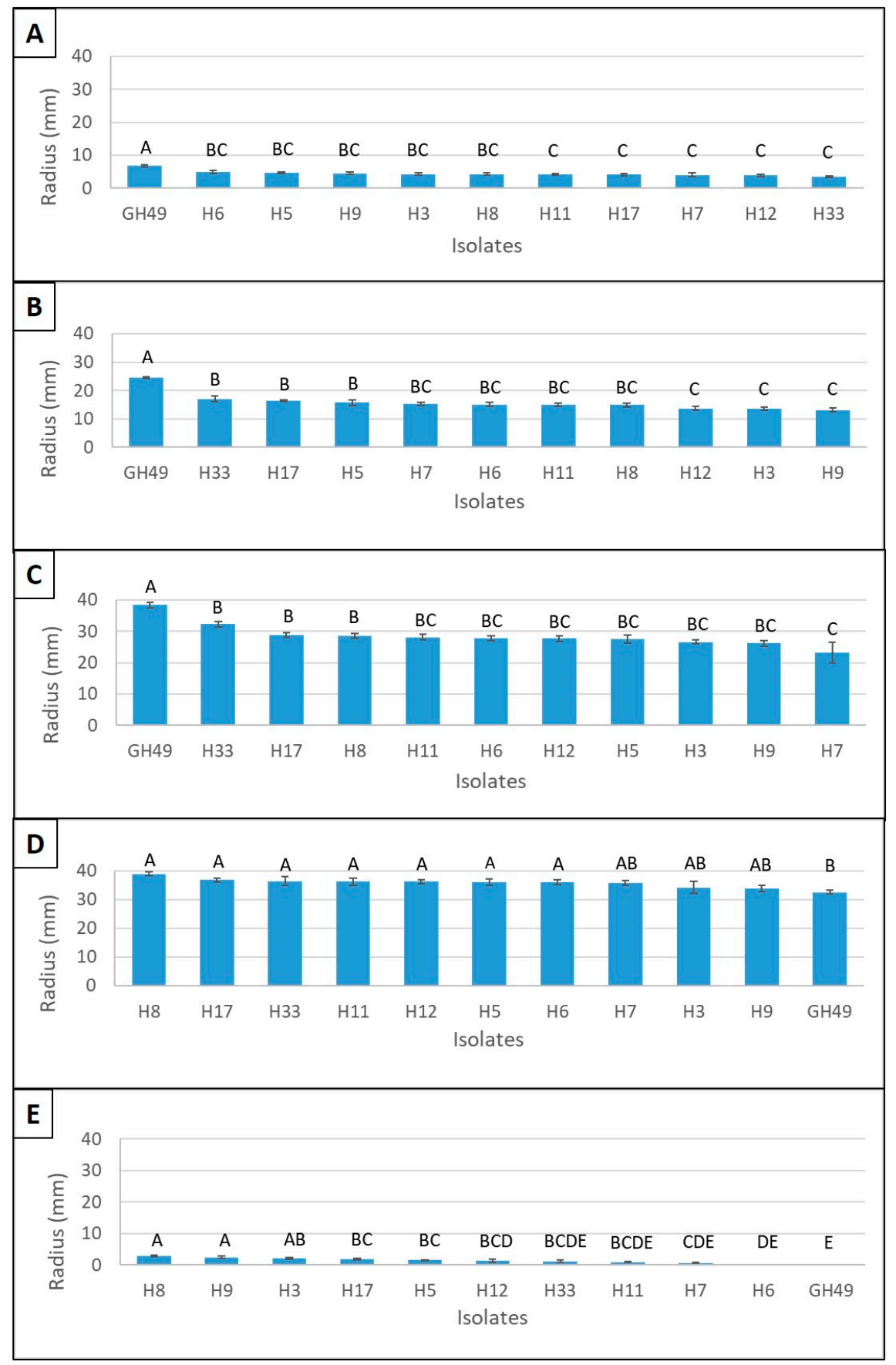

Figure 3. Effect of temperature on growth of Phytophthora palmivora. Mean radial growth after three days at (A) $15{ }^{\circ} \mathrm{C}$, (B) $20^{\circ} \mathrm{C}$, (C) $25^{\circ} \mathrm{C}$, (D) $30^{\circ} \mathrm{C}$, and (E) $35^{\circ} \mathrm{C}$ of P. palmivora isolates from cacao in Hawaii $(n=10)$ and Ghana $(n=1 ; \mathrm{GH} 49)$. Columns with same letters above the bars are not significantly different $(p \leq 0.05)$. No growth was observed at $10{ }^{\circ} \mathrm{C}$. 


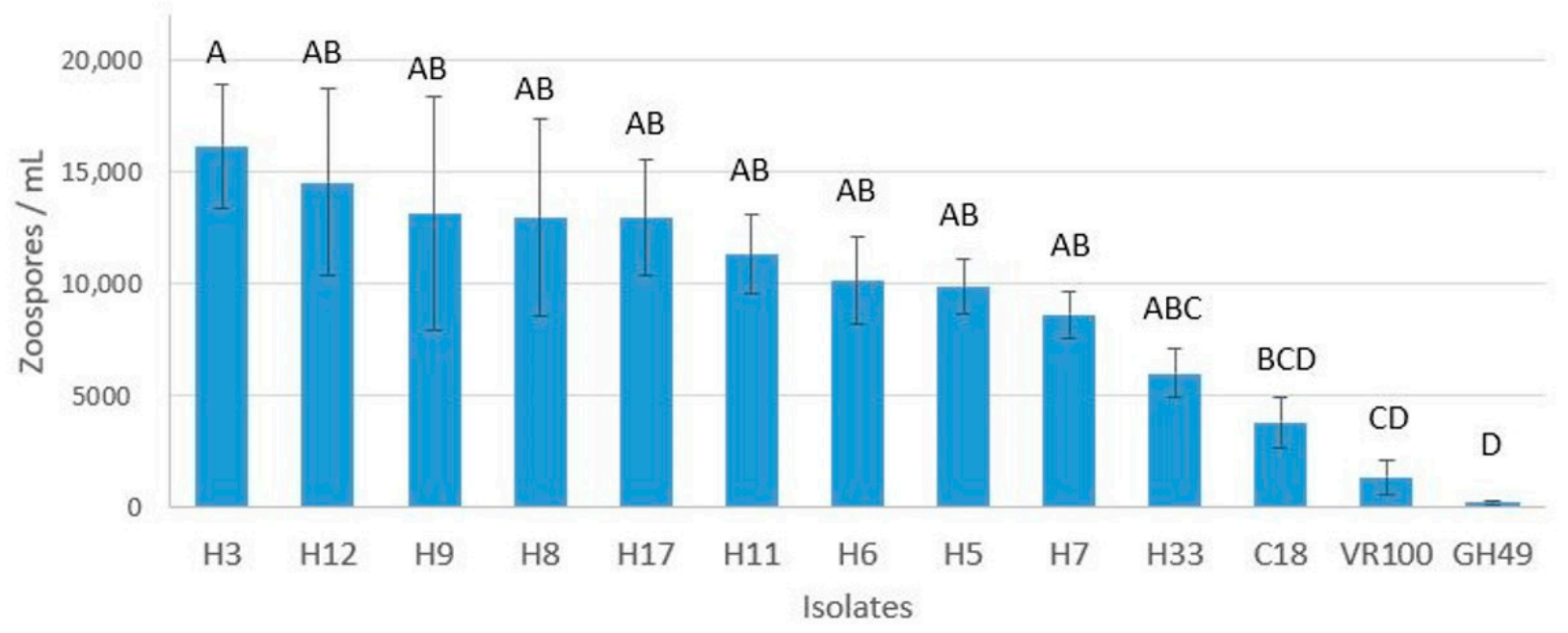

Figure 4. Zoospore production per $\mathrm{cm}^{2}$ of colony. Mean concentration of zoospores produced by Phytophthora palmivora isolates pathogenic on cacao. Isolates sharing the same letters above the bars are not significantly differ $(p \leq 0.05)$. Bars represent standard errors.

\subsection{Virulence Screening}

Unwounded pod husk inoculations were carried out to assess variation in virulence among P. palmivora isolates collected in this study. ANOVA analysis showed significant differences in the lesion radii four days post-inoculation $(p \leq 0.05)$. Although $\mathrm{H7}$ produced the lesions with the largest mean radii $18.5 \mathrm{~mm}( \pm 12.5 \mathrm{~mm})$, there was high variation among replicates and no statistically significant differences were detected (Figure 5). Differences in mean lesion radii were only identified between $\mathrm{H} 3(10.9 \pm 1.6 \mathrm{~mm})$ vs. H8 and H6 $(1.3 \pm 0.95 \mathrm{~mm}$ and $1.3 \pm 0.76 \mathrm{~mm}$, respectively). $\mathrm{H} 8$ and $\mathrm{H} 6$ produced lesions with the lowest mean radii, since only $10 \%$ of pieces inoculated with these isolates developed symptoms. The pathogen was reisolated from a subset of lesions to verify that the causal agent was P. palmivora. No lesions developed on the negative controls.

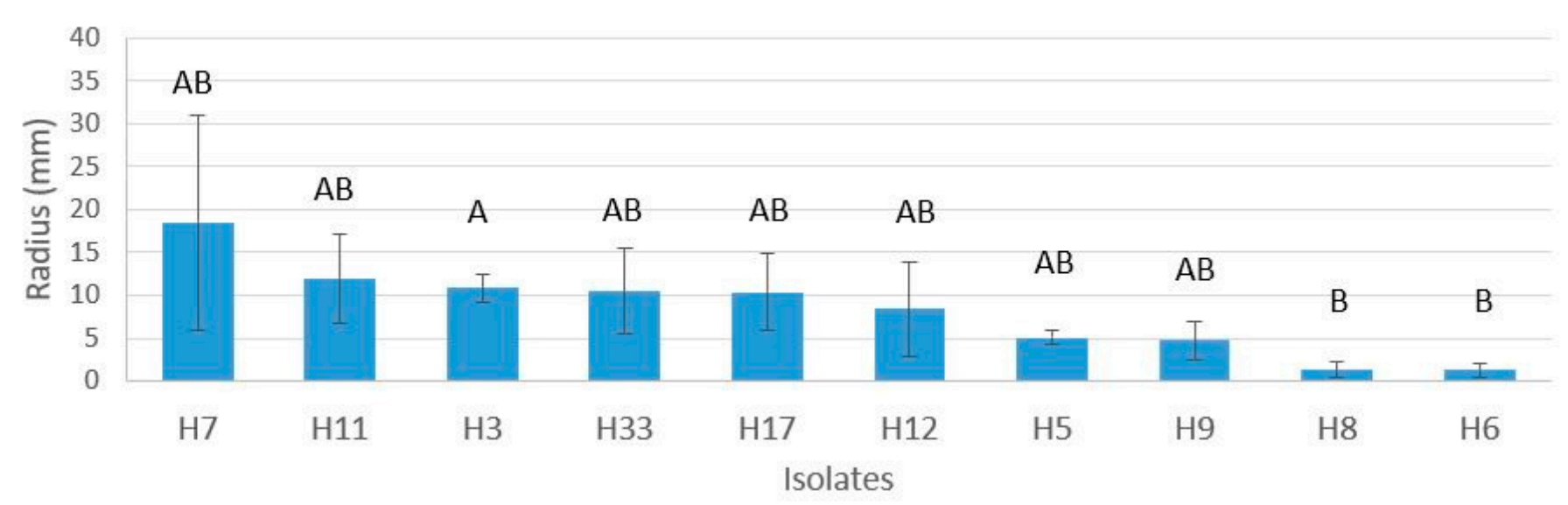

Figure 5. Lesion radius 4 days post-inoculation. Relative virulence of Phytophthora palmivora isolates causing disease on Theobroma cacao in Hawaii was quantified as lesion radii four days post-inoculation. Isolates sharing the same letters above the bars are not significantly different $(p \leq 0.05)$. Untransformed means are displayed in the figure, and bars represent standard errors.

\subsection{Fungicide Sensitivity Assay}

Relationships between fungicide concentration and inhibition (\% mycelial growth reduction) of four commonly used fungicides were compared.

Chlorothalonil. C18 and VR100 had the highest $\mathrm{EC}_{50}$ values $(45.5$ and $44.8 \mu \mathrm{g} / \mathrm{mL}$, respectively); however, they did not differ significantly from any of the Hawaii isolates 
(Table 2). The lowest EC50 was for GH49 $(10.5 \mu \mathrm{g} / \mathrm{mL})$, which differed significantly from all isolates, except $\mathrm{H} 11$ and C18, whose $95 \%$ confidence intervals (CI's) had particularly large ranges $(9.5-66.4 \mu \mathrm{g} / \mathrm{mL}$ for $\mathrm{H} 11$ and $13.0-159.3 \mu \mathrm{g} / \mathrm{mL}$ for C18). Hawaii isolates did not differ among each other in their response to chlorothalonil.

Table 2. Chlorothalonil mean $\mathrm{EC}_{50}$ values (effective fungicide concentration that inhibited mycelial growth by 50\%) for Phytophthora palmivora isolates from Ghana (GH49 and VR100), Mexico (C18), and Hawaii (H5, H7, H11, and H33) obtained from in vitro assays. Mean separation is based upon whether confidence intervals overlap, columns with the same letter are not significantly different.

\begin{tabular}{|c|c|c|c|c|c|}
\hline \multicolumn{3}{|c|}{$\mathrm{EC}_{50}(\mu \mathrm{g} / \mathrm{mL})$} & \multicolumn{2}{|l|}{$95 \% \mathrm{CI}^{\mathrm{a}}$} & \multirow[b]{2}{*}{$y=0.79 x+3.66$} \\
\hline $\mathrm{C} 18$ & 45.5 & $\mathrm{AB}$ & $13.0-159.3$ & 0.95 & \\
\hline VR100 & 44.8 & A & $29.2-68.7$ & 0.93 & $y=0.86 x+3.53$ \\
\hline H33 & 30.7 & A & $22.0-42.9$ & 0.93 & $y=1.02 x+3.43$ \\
\hline H5 & 26.9 & A & $18.5-39.2$ & 0.99 & $y=1.02 x+3.55$ \\
\hline $\mathrm{H} 7$ & 25.5 & A & $17.5-37.0$ & 0.97 & $y=1.28 x+3.23$ \\
\hline H11 & 25 & $\mathrm{AB}$ & $9.5-66.4$ & 0.99 & $y=0.97 x+3.64$ \\
\hline GH49 & 10.5 & B & $7.4-15.0$ & 0.98 & $y=1.442 x+3.41$ \\
\hline
\end{tabular}

a $95 \%$ confidence interval $(p=0.05)$.

Mancozeb. Isolates did not differ in terms of sensitivity to Mancozeb, with $\mathrm{EC}_{50}$ values ranging from $29.5-41.5 \mu \mathrm{g} / \mathrm{mL}$ (Table 3 ). $\mathrm{H} 11$ had the lowest $\mathrm{R}^{2}$ value (0.67) meaning only $67 \%$ of the variation in effectiveness is explained by fungicide concentration for that isolate. All other isolates had $\mathrm{R}^{2}$ values ranging from 0.75 to 0.92 .

Table 3. Mancozeb mean $\mathrm{EC}_{50}$ values (effective fungicide concentration that inhibited mycelial growth by 50\%) for Phytophthora palmivora isolates from Ghana (GH49 and VR100), Mexico (C18), and Hawaii (H5, H7, H11, and H33) obtained from in vitro assays. No $\mathrm{EC}_{50}$ values differed significantly among isolates, as determined by the overlap in confidence intervals.

\begin{tabular}{ccccc}
\hline & $\mathbf{E C}_{\mathbf{5 0}}(\boldsymbol{\mu g} / \mathbf{m L})$ & $\mathbf{9 5} \mathbf{~ C I}^{\mathbf{a}}$ & $\mathbf{R}^{2}$ & \\
\hline C18 & 41.5 & $29.9-57.5$ & 0.81 & $\mathrm{y}=0.96 \mathrm{x}+3.31$ \\
H11 & 41.5 & $22.8-75.7$ & 0.67 & $\mathrm{y}=0.62 \mathrm{x}+3.93$ \\
H7 & 41.1 & $22.8-74.1$ & 0.75 & $\mathrm{y}=0.62 \mathrm{x}+3.94$ \\
VR100 & 40.3 & $30.2-53.8$ & 0.90 & $\mathrm{y}=1.25 \mathrm{x}+2.87$ \\
GH49 & 31.6 & $24.7-40.4$ & 0.88 & $\mathrm{y}=1.30 \mathrm{x}+2.97$ \\
H5 & 29.7 & $19.3-46.17$ & 0.89 & $\mathrm{y}=0.78 \mathrm{x}+3.83$ \\
H33 & 29.5 & $20.2-42.9$ & 0.92 & $\mathrm{y}=0.90 \mathrm{x}+3.66$ \\
\hline
\end{tabular}

Mefenoxam. For mefenoxam, $\mathrm{EC}_{50}$ ranged from $0.23 \times 10^{-3} \mu \mathrm{g} / \mathrm{mL}$ (H7) to $0.168 \mu \mathrm{g} / \mathrm{mL}$ (C18) (Table 4). The isolate with the highest $\mathrm{EC}_{50}$ was $\mathrm{C} 18(0.168 \mu \mathrm{g} / \mathrm{mL})$, followed by GH49 and VR100 $(0.0756 \mu \mathrm{g} / \mathrm{mL}$ and $0.0387 \mu \mathrm{g} / \mathrm{mL}$, respectively). Although the P. palmivora isolates from Hawaii did not differ among each other, $\mathrm{C} 18$ and GH49 had significantly higher $\mathrm{EC}_{50}$ than the Hawaii isolates. Although VR100 was at least 38x greater than the least sensitive Hawaii isolate $(\mathrm{H} 5,0.001 \mathrm{ug} / \mathrm{mL})$, it was not significantly different as determined based on 95\% CI.

Fosetyl-Al. $\mathrm{EC}_{50}$ values for fosetyl-Al ranged from $0.594 \mu \mathrm{g} / \mathrm{mL}$ (H7) to $43.25 \mu \mathrm{g} / \mathrm{mL}$ (C18) (Table 5). However, the only statistically significant differences were between VR100 $(19.64 \mu \mathrm{g} / \mathrm{mL})$ and $\mathrm{H} 7(0.594 \mu \mathrm{g} / \mathrm{mL})$.

For all fungicides tested, $\mathrm{C} 18$ had the highest $\mathrm{EC}_{50}$ values, and VR100 had the second and third highest $\mathrm{EC}_{50}$ for chlorothalonil, fosetyl-Al, and mefenoxam, respectively. Although $\mathrm{H} 7$ had the lowest $\mathrm{EC}_{50}$ in two of the four fungicides tested (mefenoxam and fosetyl-Al), no significant differences were found among Hawaii isolates tested, as determined by overlapping $95 \%$ CI. 
Table 4. Mefenoxam mean $\mathrm{EC}_{50}$ values (effective fungicide concentration that inhibited mycelial growth by 50\%) for Phytophthora palmivora isolates from Ghana (GH49 and VR100), Mexico (C18), and Hawaii (H5, H7, H11, and H33) obtained from in vitro assays. Mean separation is based upon whether confidence intervals overlap, columns with the same letter are not significantly different.

\begin{tabular}{|c|c|c|c|c|c|}
\hline & \multicolumn{2}{|c|}{$\mathrm{EC}_{50}\left(\times 10^{-3}\right)^{\mathrm{a}}(\mu \mathrm{g} / \mathrm{mL})$} & $95 \% \mathrm{CI}^{\mathrm{b}}\left(\times 10^{-3}\right)$ & $\mathbf{R}^{2}$ & \\
\hline $\mathrm{C} 18$ & 168.2 & A & $84.8-333.8$ & 0.66 & $y=0.56 x+5.53$ \\
\hline GH49 & 75.6 & A & $37.3-153.2$ & 0.61 & $y=0.58 x+5.99$ \\
\hline VR100 & 38.7 & $\mathrm{AB}$ & $12.1-123.6$ & 0.57 & $y=0.43 x+5.81$ \\
\hline H5 & 1.14 & B & $0.048-27.1$ & 0.87 & $y=0.33 x+6.08$ \\
\hline H11 & 0.397 & B & $0.006-25.6$ & 0.75 & $y=0.27 x+6.08$ \\
\hline H33 & 0.319 & B & $0.00496-20.5$ & 0.71 & $y=0.29 x+6.20$ \\
\hline $\mathrm{H} 7$ & 0.234 & B & $0.0026-21.0$ & 0.88 & $y=0.28 x+6.12$ \\
\hline
\end{tabular}

${ }^{\mathrm{a}}$ For clarity, all $\mathrm{EC}_{50}$ and $95 \% \mathrm{CI}$ values are $10^{-3} ; \mathrm{b} 95 \%$ confidence interval $(p=0.05)$.

Table 5. Fosetyl-Al mean $\mathrm{EC}_{50}$ values (effective fungicide concentration that inhibited mycelial growth by 50\%) for Phytophthora palmivora isolates from Ghana (GH49 and VR100), Mexico (C18), and Hawaii (H5, H7, H11, and H33) obtained from in vitro assays. Mean separation is based upon whether confidence intervals overlap, columns with the same letter are not significantly different.

\begin{tabular}{|c|c|c|c|c|c|}
\hline & \multicolumn{2}{|c|}{$\mathrm{EC}_{50}(\mu \mathrm{g} / \mathrm{mL})$} & $95 \% \mathrm{CI}^{\mathrm{a}}$ & $\mathbf{R}^{2}$ & \\
\hline $\mathrm{C} 18$ & 43.25 & $\mathrm{AB}$ & $5.73-326.4$ & 0.62 & $y=1.11 x+3.44$ \\
\hline VR100 & 19.64 & A & $8.56-45.07$ & 0.79 & $y=1.47 x+3.11$ \\
\hline H5 & 13.03 & $\mathrm{AB}$ & $3.14-54.10$ & 0.70 & $y=1.35 x+3.36$ \\
\hline GH49 & 6.81 & $\mathrm{AB}$ & $1.65-28.05$ & 0.82 & $y=0.88 x+4.51$ \\
\hline H33 & 4.18 & $\mathrm{AB}$ & $0.22-78.41$ & 0.54 & $y=1.02 x+3.53$ \\
\hline H11 & 2.12 & $\mathrm{AB}$ & $0.05-89.92$ & 0.58 & $y=1.11 x+3.62$ \\
\hline $\mathrm{H} 7$ & 0.594 & B & $0.057-6.24$ & 0.79 & $y=0.80 x+5.09$ \\
\hline
\end{tabular}

a $95 \%$ confidence interval $(p=0.05)$.

\section{Discussion}

Presence of P. palmivora was confirmed on only three of the eight sites surveyed, which was surprising considering the reported presence of this pathogen in all cacao producing areas. Failure to detect the pathogen on Oahu Island was also unexpected as two of the sites surveyed are among the first places where T. cacao was planted on the island, and currently serve as germplasm repositories. Two diseased pod samples from site 8 yielded Neofusicoccum parvum, the same organism found to be causing pod disease on site 4 . This organism was recently found to be the cause of pod rot on T. cacao [23], which highlights the importance of confirming pathogen identity via isolation before attributing field symptoms to P. palmivora.

A major distinction between the three sites where P. palmivora was detected is the relatively high level of precipitation, 3239 to $3459 \mathrm{~mm}$ vs. 467 to $814 \mathrm{~mm}$ for the remaining sites. However, more detailed collections would need to be carried out before identifying this as the limiting factor. On Hawaii Island, the two sites from which no P. palmivora was isolated (sites 4 and 5) differ from the others by their lower average temperatures (14.3 and $16{ }^{\circ} \mathrm{C}$ vs. 21.3 to $21.8{ }^{\circ} \mathrm{C}$ ), which are outside the range in which P. palmivora grows well [24]. Infection is believed to occur overnight, as the temperature reduction in the evening increases the chances of dew forming on leaf surfaces which then induces zoospore release and germination of Phytophthora spp. sporangia. However, the ability of the pathogen to infect, even in the presence of free water, may be limited if nighttime temperatures fall below a certain threshold.

Despite the presence of BPR in Hawaii being reported in an extension bulletin, Phytophthora spp. isolated from cacao in Hawaii are not mentioned in any peer-reviewed publications. Aragaki and Uchida [25] examined morphological variation in 53 isolates of Phytophthora tropicalis sp. nov. from several hosts most of which were collected in Hawaii. 
However, all isolates from T. cacao were collected in Brazil. In addition, no evidence of molecular identification was found in GenBank.

Due to the presence of Hawaii outside of the northernmost limit typically accepted for commercial production, it was expected that isolates found on the islands would have a lower temperature range than GH49, an isolate from Ghana, considered representative of in vitro growth of African P. palmivora isolates [19]. Despite this, GH49 had the highest growth rate at all temperatures at or below $25{ }^{\circ} \mathrm{C}$. This dynamic was inverted at $30{ }^{\circ} \mathrm{C}$ and $35^{\circ} \mathrm{C}$, where all Hawaii isolates outgrew GH49. In addition, growth rates differed significantly among Hawaii isolates, with $\mathrm{H} 33$ and $\mathrm{H} 17$ frequently being the highest.

The production and release of zoospores in vitro represents a specific component of the disease cycle. Although several structures are infective, zoospores are believed to be responsible for rapid increases in infection, due to their production in greater number, and more efficient germination [26,27]. Zoospore production per colony area $\left(\mathrm{cm}^{2}\right)$ was assessed to identify phenotypic variation within isolates from Hawaii, and among isolates collected worldwide.

No differences in zoospore production were detected among the Hawaii isolates but these differed significantly from the isolates from Ghana. Although zoospore production of Hawaii isolates tended to be greater than that of isolates from Ghana and Mexico, indicating differences among various parts of the world, Hawaii isolates are also distinct in that they were isolated more recently. It is possible that reduced zoospore production occurs following successive mycelial transfer of organisms in culture. GH49 has been used extensively in inoculation studies, where the inoculum concentration $\left(10^{5}\right.$ zoospores $\left./ \mathrm{mL}\right)$ was several-fold greater than what was produced during this study using the same protocol [19].

Although growth rate and zoospore production are important epidemiological components of the disease cycle, they are not necessarily indicative of virulence level. While growth rate in culture is expected to reflect primarily the rate of colonization of plant tissue, the inoculation study on unwounded pod husks was conducted to determine whether virulence varied in the group of isolates collected. Statistically significant differences in pathogenicity were only identified between $\mathrm{H} 3$ vs. H8 and H6. Pod pieces inoculated with $\mathrm{H} 3$ produced lesions nearly ten-fold larger than those inoculated with $\mathrm{H} 8$ and $\mathrm{H} 6$. Interestingly, only $10 \%$ of pieces inoculated with $\mathrm{H} 8$ and $\mathrm{H} 6$ developed symptoms.

The percent reduction in mycelial growth at a range of concentrations was measured to determine relative sensitivity of isolates to fungicides active against oomycetes. Two of the four chemicals tested, fosetyl- $\mathrm{Al}$ and mefenoxam, are the fungicides most frequently used to control Phytophthora spp. on cacao. Although results of in vitro assays do not correlate directly with the performance of fungicides in the field [28], they provide an initial estimate of an isolate's sensitivity. The purpose of these assays was to determine whether the response of P. palmivora isolates affecting cacao in Hawaii differ from those in other areas around the world.

Fungicide sensitivities were similar among Hawaii isolates, with no significant differences detected among their $\mathrm{EC}_{50}$ values. Differences between Hawaii and control isolates were detected in their responses to chlorothalonil, mefenoxam, and fosetyl-Al. The most distinct differences between Hawaii and control isolates were in response to mefenoxam.

Low levels of mancozeb, chlorothalonil, and fosetyl-Al were found to induce growth in some isolates. Growth was induced on plates of at $0.1 \mathrm{ppm}$ chlorothalonil for GH49 and H7, and at 0.1 and 1 ppm of mancozeb for GH49 and VR100. Fosetyl-Al stimulated growth in many isolates at $1 \mathrm{ppm}$ (except GH49 and H7) followed by progressively larger reductions in growth at 10,100, and $1000 \mathrm{ppm}$ (Supplemental File 2). Although effect of fungicides on mycelial growth is a valuable measure of isolate response, other stages of growth and development are more sensitive to fungicides and become impaired at lower concentrations. Bruck et al. [29] stated that most important effects of chlorothalonil and mancozeb on $P$. infestans were their ability to inhibit spore germination and reduce viability of sporangia produced on treated plant material. 
The least effective fungicide was chlorothalonil, with isolates C18 and VR100 showing only 67.1 and $69.9 \%$ reductions in mycelial growth on plates amended with $100 \mathrm{ppm}$. Miyake and Nagai [30] found that $\mathrm{EC}_{50}$ for chlorothalonil on mycelial growth of 3 isolates of P. palmivora ranged from 0.8 to $2.1 \mu \mathrm{g} / \mathrm{mL}$. This was not supported by the results of this study, where $\mathrm{EC}_{50} \mathrm{~s}$ ranged from 10.5 to $45.5 \mu \mathrm{g} / \mathrm{mL}$. Most Hawaii isolates were significantly less sensitive than GH49 to chlorothalonil $\left(\mathrm{EC}_{50} \mathrm{~s}\right.$ of 25.5 to $30.7 \mu \mathrm{g} / \mathrm{mL}$ vs. $10.5 \mu \mathrm{g} / \mathrm{mL}$ ). This fungicide inhibits all stages of pathogen growth [29] and suppresses oospore production in vitro, in contrast to mancozeb and mefenoxam [31]. It has been suggested that resistance to Chlorothalonil may be due to the detoxifying action of thiols produced by fungi [32].

Mancozeb is a protectant fungicide with multisite inhibitory activity that results in little or no selection. Despite the wide range of sensitivities among P. infestans in Brazil (EC $\mathrm{E}_{50}$ values from $<1 \mu \mathrm{g} / \mathrm{mL}$ to $25.7 \mu \mathrm{g} / \mathrm{mL}$ ) [33], Grünwald et al. [34] found that repeated use of mancozeb in a single growing season did not select for $P$. infestans with reduced sensitivity. Tey and Wood [35] calculated an $\mathrm{EC}_{50}$ of $24 \mu \mathrm{g} / \mathrm{mL}$ for mancozeb on mycelial growth of $P$. palmivora isolated from cacao, which was comparable to the $\mathrm{EC}_{50}$ s found in this study (29.7 to $41.5 \mu \mathrm{g} / \mathrm{mL}$ ). This was the only chemical to which no differences in sensitivity were detected among isolates. Chlorothalonil and mancozeb are multi-site contact fungicides, considered low risk regarding the potential for pathogens to develop resistance [36]. No pathogen resistance or insensitivity to either compound has been reported.

Mefenoxam is a systemic phenylamide fungicide that inhibits RNA synthesis. It is among the most effective chemical controls against oomycete pathogens [37]; however, fungicide resistance develops in the field following prolonged use [38-40]. Sensitive isolates have been shown to acquire tolerance following a single passage on mefenoxam-containing media [41]. In this study, mefenoxam was the most effective fungicide, with 87.4 to $93.3 \%$ reduction in mycelial growth obtained with 1 ppm. However, at higher concentrations, little, if any, additional growth reductions were obtained.

Torres-Londono [42] reported an $\mathrm{EC}_{50}$ for mefenoxam on P. palmivora as $0.017 \mu \mathrm{g} / \mathrm{mL}$ (ranging from 0.003 to $0.105 \mu \mathrm{g} / \mathrm{mL}$ for the 150 isolates tested). The least sensitive isolates in this study, $\mathrm{C} 18$ and $\mathrm{GH} 49$, had $\mathrm{EC}_{50}$ values within the published range $(0.17$ and $0.08 \mu \mathrm{g} / \mathrm{mL}$, respectively) but they differed significantly from the Hawaii isolates. Isolates from Hawaii $\mathrm{EC}_{50} \mathrm{~s}(0.0002$ to $0.0004 \mu \mathrm{g} / \mathrm{mL})$, several-fold smaller than those published [42]. Previous reports of increased mefenoxam resistance being associated with slower growth in culture [41], was not reflected in this study as the isolates least sensitive to mefenoxam also had with the greatest growth rates.

Although none of the isolates in this study were found to be resistant to mefenoxam according to the various published criteria $[39,41,43]$ isolates from Hawaii are significantly more sensitive to this compound than the control isolates which are from areas where cacao is more widely grown. It is possible that the latter have had greater exposure to mefenoxam, and thus, are developing resistance to this class of compounds.

Fosetyl-Al (Aliette) is a systemic fungicide used to control plant-infecting oomycete pathogens [44]. Inside the plant, it ionizes into phosphonate, which functions by inducing host plant defenses as well as having a direct mode of action on the pathogen [44,45]. Although it is listed as a compound with a low risk of inducing pathogen resistance [36], populations of $P$. cinnamomi showed reduced sensitivity to phosphonates following long term use [46]. In addition, naturally occurring resistance to fosetyl-Al was found in $P$. infestans isolates known to be resistant to metalaxyl [47].

The high variability of in vitro responses of P. palmivora to fosetyl-Al seen here is consistent with the wide range of published $\mathrm{EC}_{50}$ values. For in vitro inhibition of mycelial growth of P. capsici, $\mathrm{EC}_{50}$ values range from $50 \mu \mathrm{g} / \mathrm{mL}$ [48] to $103 \mu \mathrm{g} / \mathrm{mL}$ [49], and 30.8 [49] to $929 \mu \mathrm{g} / \mathrm{mL}$ [50] for P. parasitica.

In this study, $\mathrm{EC}_{50}$ values for fosetyl-Al ranged from $0.59 \mu \mathrm{g} / \mathrm{mL}$ for the Hawaii isolate $\mathrm{H} 7$, to $43.25 \mu \mathrm{g} / \mathrm{mL}$ for isolate $\mathrm{C} 18$. The only published report using a P. palmivora isolate from cacao [51], calculated an $\mathrm{EC}_{50}$ value of $20.31 \mu \mathrm{g} / \mathrm{mL}$, which is in the center 
of the range found in this study. The $\mathrm{EC}_{50}$ for zoosporangium production in P. palmivora is $0.3 \mu \mathrm{g} / \mathrm{mL}$ [52], suggesting other forms of pathogen development may be inhibited at levels lower than those inhibiting mycelial growth.

\section{Conclusions}

All Phytophthora spp. isolates collected during this study were confirmed to be $P$. palmivora. Although no differences were found at the molecular level, they differed among each other in terms of their temperature responses and virulence. Isolates collected in Hawaii differed from P. palmivora from Ghana and Mexico in temperature response, zoospore production, and fungicide sensitivity. Despite the relatively colder climate, Hawaii isolates grew significantly more than the control (GH49) at high temperature $\left(30^{\circ} \mathrm{C}\right.$ and $35^{\circ} \mathrm{C}$ ). However, it is not clear if this will translate into increased virulence at these temperatures. In addition, P. palmivora affecting T. cacao in Hawaii are significantly more sensitive to mefenoxam than the isolates from regions with more established cacao industries. Although no data on fungicide use in Hawaii is available, few cacao farmers in the state are thought to treat BPR with fungicides [53].

Although high levels of precipitation are cited as promoting Phytophthora spp. infection, cacao farms in drier climates can also experience high levels of disease [54]. The absence of P. palmivora on the drier side of Hawaii Island may be partly due to the colder temperatures of these higher elevation sites. Thus, cacao farms on the leeward sides of the islands in the state of Hawaii could still become infected with P. palmivora. The USDA-ARS, in collaboration with HARC, are currently evaluating cacao clones on the islands of Hawaii and Oahu for their productivity and disease resistance. The isolates of P. palmivora obtained during this study can be used to screen clones using artificial inoculation, taking care to avoid $\mathrm{H} 6$ and $\mathrm{H} 8$.

Although the number of sites surveyed in this study was sufficient to determine a general prevalence of the pathogen and the species, more detailed surveys encompassing all the islands where cacao is produced are needed before drawing conclusions regarding factors limiting the establishment of $P$. palmivora. Monitoring and characterization of the pathogen population, including fungicide resistance and temperature response, provide valuable information for use in developing effective disease management strategies.

Supplementary Materials: The following are available online at https:/ /www.mdpi.com/article/10 .3390/agriculture11050396/s1, Supplemental File 1: Mean separation tables for zoospore production, virulence, and temperature response assays, Supplemental File 2: Fungicide sensitivity assay data.

Author Contributions: Conceptualization, A.S.P. and J.-P.M.; methodology, A.S.P., J.-P.M., T.M., L.K.; software, A.S.P., J.-P.M., T.M.; validation, A.S.P., W.Q.; formal analysis, A.S.P.; investigation, A.S.P., T.M., W.Q., L.K.; resources, A.S.P., J.-P.M., O.A.G.; data curation, W.Q., A.S.P.; writing—original draft preparation, A.S.P., L.K., W.Q., O.A.G., T.M., J.-P.M.; writing—review and editing, A.S.P., L.K., W.Q., O.A.G., T.M., J.-P.M.; visualization, A.S.P.; supervision, A.S.P.; project administration, A.S.P., J.-P.M.; funding acquisition, A.S.P., J.-P.M., O.A.G. All authors have read and agreed to the published version of the manuscript.

Funding: This research was funded by MARS, Incorporated (grant no. 58-6631-6-123).

Data Availability Statement: Data are available in the manuscript text and in the supplemental files.

Acknowledgments: We would like to thank Susan Schenck, Chifumi Nagai, and Tyler Jones from Hawaii Agriculture Research Center, Kunia, HI for assisting with the sampling on Oahu, and Lionel Sugiyama and Marc Hughes from USDA-ARS, Hilo HI for sharing their technical expertise.

Conflicts of Interest: The authors declare no conflict of interest.

\section{References}

1. Bittenbender, H.C. History of Cacao in Hawaii; Hawaii Cacao Symposium: Kona, HI, USA, 2005.

2. Fleming, K.; Smith, V.E.; Bittenbender, H.C. The Economics of Cacao Production in Kona. AgriBusiness 2009, AB-17. Available online: http:/ /hdl.handle.net/10125/13442 (accessed on 19 April 2021). 
3. Bittenbender, H.C. 2015 Hawaii Cacao Survey. Available online: http://deepdirtcacao.com/2015HawaiiCacaoSurvey.pdf (accessed on 19 April 2021).

4. USDA. Hawaii Tropical Fruits and Crops Report 2016. Available online: https://www.nass.usda.gov/Statistics_by_State/Hawaii/ Publications/Sugarcane_and_Specialty_Crops/Sugarcane/2017/201709tropicalspecialtiesHI.pdf (accessed on 19 April 2021).

5. Hebbar, P.; Bittenbender, H.; O'Doherty, D. Farm and forestry production and marketing profile for cacao (Theobroma cacao). In Specialty crops for Pacific Island Agroforestry; Elevitch, C.R., Ed.; Permanent Agriculture Resources (PAR): Holualoa, HI, USA, 2011.

6. Brasier, C.M. The biosecurity threat to the UK and global environment from international trade in plants. Plant Path. 2008, 57, 792-808. [CrossRef]

7. Guest, D. Black pod: Diverse pathogens with a global impact on cocoa yield. Phytopathology 2009, 97, 1650-1653. [CrossRef]

8. Dennis, J.J.; Konam, J.K. Phytophthora palmivora: Cultural control methods and their relationship to disease epidemiology on cocoa in PNG. In Proceedings of the 11th International Cocoa Research Conference, Yamoussoukro, Cote D'Ivoire, 18-24 July 1993; Cocoa Producers Alliance: London, UK, 1994; pp. 953-957.

9. Gregory, P.H.; Maddison, A. Epidemiology of Phytophthora on Cocoa in Nigeria; Commonwealth Mycological Institute: Kew, $\mathrm{UK}, 1981$.

10. Opoku, I.Y.; Akrofi, A.Y.; Appiah, A.A. Assessment of sanitation and fungicide application directed at cocoa tree trunks for the control of Phytophthora black pod infections in pods growing in the canopy. Eur. J. Plant Pathol. 2007, 117, 167-175. [CrossRef]

11. Chee, K.; Foong, K. Use of cacao pod for recovering Phytophthora species pathogenic to Hevea brasiliensis. Plant Dis. Report. 1968, 52, 5 .

12. U.S. Climate Data. Available online: https://www.usclimatedata.com/ (accessed on 27 September 2018).

13. Weatherbase. Available online: https://www.weatherbase.com (accessed on 27 September 2018).

14. Climate-Data.Org. Available online: https:/ / en.climate-data.org/ (accessed on 27 September 2018).

15. Topozone. Available online: https://www.topozone.com/ (accessed on 27 September 2018).

16. World Weather and Climate Information. Available online: https://weather-and-climate.com (accessed on 27 September 2018).

17. White, T.J.; Bruns, T.; Lee, S.; Taylor, J.W. Amplification and direct sequencing of fungal ribosomal RNA genes for phylogenetics. In PCR Protocols: A Guide to Methods and Applications; Innis, M.A., Gelfand, D.H., Sninsky, J.J., White, T.J., Eds.; Academic Press, Inc.: New York, NY, USA, 1990; pp. 315-322.

18. Hudspeth, D.S.; Nadler, S.A.; Michael, E.S.H. A COX2 Molecular Phylogeny of the Peronosporomycetes. Mycologia 2000, 92, 674-684. [CrossRef]

19. Ali, S.S.; Amoako-Attah, I.; Bailey, R.A.; Strem, M.D.; Schmidt, M.; Akrofi, A.Y.; Surujdeo-Maharaj, S.; Kolawole, O.O.; Begoude, B.A.D.; Hoopen, G.M.; et al. PCR-based identification of cacao black pod causal agents and identification of biological factors possibly contributing to Phytophthora megakarya's field dominance in West Africa. Plant Pathol. 2016, 65, 1095-1108. [CrossRef]

20. Srinivasan, M.R. Probit analysis. In Electronic Manual on Pesticides and Environment; Palaniswamy, S., Kuttalam, S., Chandrasekaran, S., Kennedy, J.S., Srinivasan, M.R., Eds.; Tamil Nadu Agricultural University: Tamil Nadu, India, 2004. Available online: https://www.researchgate.net/publication/312661311_Calculate_LC_50_or_LD_50_with_MS_Excel_worksheet_based_ on_Finney\%27s_method_of_probit_analysis?chanel=doi\&linkId=58879af4aca272b7b452586e\&showFulltext=true (accessed on 19 April 2021).

21. Schnell, R.J.; Olano, C.T.; Brown, J.S.; Meerow, A.W.; Cervantes-Martinez, C.; Nagai, C.; Motamayor, J.C. Retrospective determination of the parental population of superior cacao (Theobroma cacao L.) seedlings and association of microsatellite alleles with productivity. J. Am. Soc. Hortic. Sci. 2005, 130, 181-190. [CrossRef]

22. Billock, J. How Hawaii Became the North Pole of Cacao. Smithsonian Magazine. 2018. Available online: https://www. smithsonianmag.com/travel/hawaii-north-pole-cacao-chocolate-tours-180967951/ (accessed on 19 April 2021).

23. Puig, A.S.; Marelli, J.P.; Matsumoto, T.; Keith, L.; Gutierrez, O.A. First report of Neofusicoccum parvum causing pod rot on cacao in Hawaii. Plant Dis. 2019, 103, 1416. [CrossRef]

24. Puig, A.S.; Ali, S.; Strem, M.; Sicher, R.; Gutierrez, O.A.; Bailey, B.A. The differential influence of temperature on Phytophthora megakarya and Phytophthora palmivora pod lesion expansion, mycelia growth, gene expression, and metabolite profiles. Physiol. Mol. Plant Pathol. 2018, 102, 95-112. [CrossRef]

25. Aragaki, M.; Uchida, J.Y. Morphological Distinctions between Phytophthora capsici and P. tropicalis sp. nov.. Mycologia 2001, 93, 137-145. [CrossRef]

26. Hwu, F.Y.; Lai, M.W.; Liou, R.F. PpMID1 Plays a Role in the Asexual Development and Virulence of Phytophthora parasitica. Front. Microbiol. 2017, 8, 610. [CrossRef] [PubMed]

27. Assinder, S.J. Molecular Genetics and Genomics of Phytophthora. In Applied Mycology and Biotechnology; Arora, D.K., Khachatourians, G.G., Eds.; Elsevier: Amsterdam, The Netherlands, 2004; Volume 4, pp. 137-160.

28. Russell, P. Sensitivity Baselines in Fungicide Resistance Research and Management; Crop Life International: Brussels, Belgium, 2002.

29. Bruck, R.; Fry, W.; Apple, A.; Mundt, C. Effect of protectant fungicides on the developmental stages of Phytophthora infestans in potato foliage. Phytopathology 1981, 100, 164-166. [CrossRef]

30. Miyake, N.; Nagai, H. Efficacy of phosphonate in controlling white powdery rot of fig caused by Phytophthora palmivora. J. Gen. Plant Pathol. 2017, 83, 390-397. [CrossRef]

31. Groves, C.T.; Ristaino, J.B. Commercial Fungicide Formulations Induce In Vitro Oospore Formation and Phenotypic Change in Mating Type in Phytophthora infestans. Phytopathology 2000, 90, 1201-1208. [CrossRef] [PubMed] 
32. Barak, E.; Edgington, L.V. Cross resistance of Botrytis cinerea to captan, thiram, chlorothalonil and related fungicides. Can. J. Plant Pathol. 1984, 6, 318-320. [CrossRef]

33. Reis, A.; Ribeiro, F.H.S.; Maffia, L.A.; Mizubuti, E.S.G. Sensitivity of Brazilian Isolates of Phytophthora infestans to Commonly Used Fungicides in Tomato and Potato Crops. Plant Dis. 2005, 89, 1279-1284. [CrossRef]

34. Grünwald, N.J.; Sturbaum, A.K.; Montes, G.R.; Serrano, E.G.; Lozoya-Saldaña, H.; Fry, W.E. Selection for Fungicide Resistance Within a Growing Season in Field Populations of Phytophthora infestans at the Center of Origin. Phytopathology 2006, 96, 1397-1403. [CrossRef]

35. Tey, C.C.; Wood, R.K.S. Effects of various fungicides in vitro on Phytophthora palmivora from cocoa. Trans. Brit. Mycol. Soc. 1983, 80, 271-282. [CrossRef]

36. Frac. Fungicide Resistance Action Committee, FRAC Code List 2018: Fungicides Sorted by Mode of Action. Available online: http:/ / www.phi-base.org/images/fracCodeList.pdf (accessed on 19 April 2021).

37. Schwinn, F.; Staub, T. Phenylamides and other fungicides against Oomycetes. In Modern Selective Fungicides: Properties, Applications, Mechanisms of Action; Lyr, H., Ed.; Longman Scientific and Technical: London, UK, 1987; pp. 259-274.

38. Moorman, G.W.; Kang, S.; Geiser, D.M.; Kim, S.H. Identification and Characterization of Pythium Species Associated with Greenhouse Floral Crops in Pennsylvania. Plant Dis. 2002, 86, 1227-1231. [CrossRef]

39. Lamour, K.H.; Hausbeck, M.K. Mefenoxam Insensitivity and the Sexual Stage of Phytophthora capsici in Michigan Cucurbit Fields. Phytopathology 2000, 90, 396-400. [CrossRef] [PubMed]

40. Ferrin, D.; Kabashima, J. In vitro insensitivity to metalaxyl of isolates of Phytophthora citricola and P. parasitica from ornamental hosts in southern California. Plant Dis. 1991, 75, 1041-1044. [CrossRef]

41. Childers, R.; Danies, G.; Myers, K.; Fei, Z.; Small, I.M.; Fry, W.E. Acquired Resistance to Mefenoxam in Sensitive Isolates of Phytophthora infestans. Phytopathology 2015, 105, 342-349. [CrossRef] [PubMed]

42. Torres-Londono, G.A. Morphological characterization, virulence, and fungicide sensitivity evaluation of Phytophthora palmivora. Ph.D. Thesis, Michigan State University, East Lansing, MI, USA, 2006. Available online: https://d.lib.msu.edu/etd/3824 (accessed on 19 April 2021).

43. Fraser, D.E.; Shoemaker, P.B.; Ristaino, J.B. Characterization of Isolates of Phytophthora infestans from Tomato and Potato in North Carolina from 1993 to 1995. Plant Dis. 1999, 83, 633-638. [CrossRef] [PubMed]

44. Cohen, Y.; Coffey, M.D. Systemic Fungicides and the Control of Oomycetes. Annu. Rev. Phytopathol. 1986, 24, 311-338. [CrossRef]

45. Mcgrath, M.T. What Are Fungicides? In The Plant Health Instructor. The American Phytopathological Society. 2004. Available online: https:/ / www.apsnet.org/edcenter/disimpactmngmnt/topc/Pages/Fungicides.aspx (accessed on 19 April 2021).

46. Vegh, I.; Leroux, P.; Le Berre, A.; Lanen, C. Détection sur Chamaecyparis lawsoniana 'Ellwoodii'd'une souche de Phytophthora cinnamomi Rands résistante au phoséthyl-Al. PHM Rev. Hortic. 1985, 262, $19-21$.

47. Cohen, Y.; Samoucha, Y. Cross-resistance to four systemic fungicides in metalaxyl-resistant strains of Phytophthora infestans and Pseudoperonospora cubensis. Plant Dis. 1984, 68, 137-139. [CrossRef]

48. Fenn, M.; Coffey, M.D. Phosphonate fungicides for control of diseases caused by Phytophthora. Calif. Avocado Soc. Yearb. 1987, 71, 241-249.

49. Matheron, M.E.; Porchas, M. Impact of Azoxystrobin, Dimethomorph, Fluazinam, Fosetyl-Al, and Metalaxyl on Growth, Sporulation, and Zoospore Cyst Germination of Three Phytophthora spp. Plant Dis. 2000, 84, 454-458. [CrossRef] [PubMed]

50. Farih, A.; Menge, J.A.; Tsao, P.H.; Ohr, H.D. Metalaxyl and efosite aluminium for control of Phytophthora gummosis and root rot on citrus. Plant Dis. 1981, 65, 654-657. [CrossRef]

51. Chan, L.; Kwee, L. Comparative in vitro sensitivity of selected chemicals on Phytophthora palmivora from cocoa and durian. Pertanika 1986, 9, 183-191.

52. Dolan, T.E.; Coffey, M.D. Correlative in vitro and in vivo behavior of mutant strains of Phytophthora palmivora expressing different resistances to phosphorous acid and fosetyl-Na. Phytopathology 1988, 78, 974-978. [CrossRef]

53. Hart, C.; (Manoa, HI, USA). Personal communication, 2018.

54. Puig, A.S.; Marelli, J.P.; Suarez-Capello, C.; Gutierrez, O.A. Phytophthora canker affecting CCN51 clones on high productivity cacao farms in Ecuador. In Proceedings of the American Phytopathological Society Annual Meeting, Plant Health, Cleveland, OH, USA, 3-7 August 2019. 